\title{
Reformation and Decentralization of Tax System, in Function of Kosovo Municipality Competences Growth - with Particular Emphasis on the Tourism Development in the Municipalities of Dukagjini Region
}

\author{
Dr.sc. Armand Krasniqi, Prof.asco. ${ }^{1}$
}

\author{
Doi:10.5901/ajis.2014.v3n2p51
}

\begin{abstract}
After the independence the Republic of Kosovo is extremely centralized and in todays it is considered one of the most centralized countries in Europe. The high level of centralization has maximally limited the competences for which the local authorities are responsible, violating the economical, financial and fiscal independence. Reforming the tax system under the principle of fiscal decentralization is important for Kosovo, because it will guarantee to the local governments the necessary resources to meet their legal, strategic and development obligations. The progress in fiscal decentralization seeks to be built on trust, confidence and mutual respect. Kosovo not only hasn't achieved significant progress in fiscal decentralization but surprisingly this issue do not even is debated in social and academic life. The today's trend and current institutional interest for the accession in EU means the urgent need for measures related to the design of a program that contains calculation of expenditure with the aim to successfully implement the reforms for fiscal decentralization and strengthening of local independence in the field of revenues which are essential for normal municipal functions. Regarding the level of decentralization, based on the circumstances and economic - social development, our system should be developed making it comparable to other EU countries because this means a duty that should be manifested in achieving international standards of decentralization.
\end{abstract}

Keywords: taxes, law, decentralization, reforms, municipal authority

\section{Introduction}

Economic and fiscal transition in Kosova oriented toward market and decentralised economy and the achieved progress on local governance were relatively visible. These achievements have put Kosova in the list of the countries that aspire to be members of EU. Actually, this is the first time that our country is close to the membership as a modern democracy. Decentralisation is without a doubt one of the most important instruments of democratisation for many developed contries and those in the transition, as well. Itself, this process is defined as a trasnfer of power and resources from the higher level to the lower ones within a political sysetm. Decentralisation usually strengthens not only the co-operation and coordination between the local organs of governance and independent ones with the official units / charge d'affairs, in the central offices of the central organs of governance but also between organs that operate within the same level. Decentralization may have a sens only if accompanied with the fiscal decentralization. This is an important request for a successful decentralization. Local governments cannot execute their functions if materials and other needed resources are not given to them so they with their own capacities realise governance functions.

On the other side, tourism as a business activity for a part of Kosova municipalities is expected to be an important part and even crucial for developing of their local economies. Within this environment as well is a basic component of assets in the touristic industry. Usually in a normal country, incomes from the tourism are used to measure the economic values of the protected zones. It is witnessed and there is no dilemma that tourism can contribute in protection of zones and sensitive habitats especially in the zones where there are such potentials. While the incomes from tarifs in order to enter into parks and into determined zones and from the similar resources can be used especially to pay on protecting and managing of sensitive environment zones in most countries, this in our case is not to be discussed at all. In our case national government collects resources in determined ways without any direct link with the specific or protected zones. Whereas used tarifs, income taxes, taxes from selling or from the rent of entertaintments equipment and tarifs from licencing activities as hunting and fishing cannot ensure in the local governments in the Dukagjini Valey normal

\footnotetext{
${ }^{1}$ The author is a professor in the Faculty of Economy in the University "Hasan Prishtina" in Prishtina for the subjects The Business Right
} and International Business Right 
management. Thus this doesn't enable the realization of enough funds to manage nature resources and consequently the qualitative local governance.

\section{Decentralisation and delegation of fiscal competences}

From the date the Kosova Constitution entered into force (June 15, 20008), the Kosova legislation along with the Law on Local Sel Governance is carachterised with the creation of a local governance framework, partially decentralized. By this law specific or mutual competences are transfered to local governments for a relatively small spectrum of service sectors. Healthcare, education, social services and agenda for economic development do not present only burdens, they present also responsibility outlined as the part of the competences of municipalities. Having in mind that these new responsibilities that are transfered to the local governments have a direct impact to citizens in each municipality, big issues and challenges by which local governmenst are faced in Kosova, are connected to the fact if they are able to exercise their new competences( Tahiri B., 2014). This type of decentralization is more of a political character and quite less accompanied by any real and seriouz form of fiscal decentralization (financial). Under these circumstances fiscal decentralization athorises local governments to collect fiscal incomes directly, so they fill up their budgets through intergovernment grants. Since the last ones are big and important (in the current stadium of decentralization in many developed countries and in all contries in development/tranzition), they represent main resources of financing local governments (The Network of Institutes and Schools of Public Administration in Central and Eastern Europe, 2012). This approach creates a paradoxal situation that is reflected with the interests of governments for monitoring the performance on spending the transfered grants more than monitoring of perfomance of spending and allocation of incomes created by local governments (at the begining local taxes). Inter-goverment grants basically are the biggest resources that are allocated to local goverments. Inter-governmental grants makes possible a control by the national government over the fiscal system at the same time offering financial support and the illusion on financial independence for the local governance levels. With the general taxes this doesn't happen. They go to a joint fund and afterwards depending on government expense policies are distributed to final uses (TNISPACEE, 2012). Fiscal inter-governmental transfers take various forms and often it is a problem to determine the best combination in order to result as a better policy of incomes. There are good and not enough good reasons on presenting the fiscal decentralization. A well projected fiscal decentralization cannot be politically dominated even though it could (usually it is) be politically initiated. Relative political power of an interest group (pressure) can initiate the process of fiscal decentralization and often can impact the selection of forms and instruments of decentralization, but this should not be the main factor for evaluation of the sucess of fiscal decentralization (TNISPACEE, 2012)

. An "ideal" decentralization could be a combination of resources from incomes of local government and those incomes from inter-governmental transfers. This form means the fact that in principle incomes are collected by local governments, to be spent independently (within the limits determined by the law) whereas in the last case, local governments are responsible before the national government on the reasons of using these fiscal resources. A part of original incomes that are actually under the responsibilities of central government (local taxes,etc) by all means should be transfered and allocated to be used by local government and no matter of the lack of the legislation this could be realized by the inter-institutional agreement (Ligji RKS Nr. 04/L-117, p2:, 2013). Local institutions, as it is the case with the municipalities of Dukagjini are not in a situation to stimulate the development of determined forms of tourism because of the centralized fiscal system we have nowadays. To argument this we may mention Law on taxes on the accomodation in the hotel and touristic objects. Based on this legal act the competence of collecting taxes is tranfered to the Tax Administration and they are allocated totally in the central government (Ligji RKS Nr. / 03/L-027, 2012) . This way of allocation of this tac is not proper because of the fact that this sum of means, taking into the consideration the level of capacities set up here, is not high for the central budget and therefore it would have been better if these means went to the municipal budget.

\section{Tax legislation in the Republic of Kosova}

The regime of taxes and tarifs in the Republic of Kosova consists of a package of laws and regulations, tax agreements that present a total mirror of all types, levels, calculations, procedures as well as methodics and forms of tax control covered by the Kosova tax system. Tax legislation is a subject of amendments and continual changes as a consequence of quick economic developments and the process of social transformations. The biggest part of fiscal norms have entered into the force on January 01, 2009. Since then there were hopes that these changes will impact the broadening of the 
basis of Kosova taxpayers in attracting new investors and gradually increasing the Kosova budget. Tax on personal incomes is considered to be the lowest, compared to those from all countries in the region. It is also the Law on Tax Administration and procedures among the others that is considered as an instrument that will facilitate a lots of cases on fulfilling the tax obligations. Therefore having a look in the system and the country tax structure, it is concluded that we talk about a contemporary and appropriate fiscal mechanism which the Kosova Government respectively Ministry of Finances considers to be in the function of economic development of our country. But up until now it is seen that the economic development of the country has stalled in all its dimensions ( UNDP report , 2013).

In additon, local governments have no competences in the sphere of fiscal policies. In the political circles it is stressed out that municipalities are autonomous only in budgetary plannings but in reality this process is determined by the central level on the basis of the governmental grant ( KIPRED , 2011).

However, it is clearly seen that in none of the government reports are not mentioned and not analyzed fields, systems and structures of taxes that remained on the competences of the local government in the country. There are no dilemmas that the current fiscal system is not harmonized with the plan of competences of central and local government and all of this in unsynchronised report with the economic development strategy. Consequently, implementation of government policies, be local ore central, not only are not harmonized, ballanced and synchronised but they have created a situation all the time the central government creates for itself a bigger scope of work related to the local government. This because there still dominates a logic that the state budget should be more relaxed due to the macro economic stability and second, municipalities can be engaged only by planning and a very limited and imposed budget, without supporting them in branches and economic activities that are considered to be priorities of development of local governemnt. This situation is not only un accepted but it is also unclear because of the fact that nobody from the institutions and experts deal deeply with this segment that is really deterring local economic development and indirectly the entire national economic development.

In order to argument the approach that governing central institutions have so they could keep this segment centralized we will deal with the follwoing case. Based on the data given by official resources from the Ministry of Environment, the application of the ecological tax in Kosova has started from July 01,2012 and since that time it was expected that the budget will bring the country two up to three miljon EUR per year (Expres, 2014). This tax applied for cars only in Koosva firstly is collected by the Center for Registering Cars from the Ministry of Interrior and it goes to the state budget. Judicial basis of this tax is found and regulated by a Special Law (Ligji Nr. 04/L-117, 2012) . Up until now this tax is collected and has gone to the state budget. Statement of the Minister for Environment according to which these means will go to the funds in order to improve environmental issues in Kosova, since this ministry in cooperation with the Ministry of Finances is preparing the Law on Fund for Environment, it results that up to date this is precise.( Albainfo , 2014).

\section{Current circumstances the inhibit fiscal decentralization}

From the fiscal point of view. Not motivated local government could be a resource of sabotage because they could see as a risk the lack of fiscal support by the central government, as a support for the interests of local community. By the other words, if the state affairs are in a good direction that a lots of possibilities will be created for local governments to increase funds in order to realize a better performance. Partnership, even in form of competition between local and central governments, is better than passivity, disinterest or continual opponence by the local government. There is no doubt that the central government is obliged to analyze, review and to project the budgetary and fiscal system treating this segment with a special attention thus protecting macro economic stability of the country. Starting from the argument of the stability of the economic system it controls all taxes.

Like in many countries of transition, it is also with ours the case, that the determination of local government expenses are an increasing burden. Difficult economic situation in one side and the need for financing of municipal needs that local governments have without complete competences related to incomes, in a continual way push the central government to pinch many duties of allocation functions, disbursements and stability in order to ensure efficient services. In our opinion and based on the opinions and attitutes of authors and various theoretician, a thought dominates that difficuties and the weaknesses of the fiscal system of the country are connected to the role of the state within the market economy, the lack of institutional culture for a long time in the country (especially 1989-2007) as well as the inhereted communist mentality for an active state in the role of tutor that gives "reason" not to give up from the influence and not to allow bigger authonomy for local governments. It is clear that this is achieved through assignement of modest responsibility for local institutions on incomes and a big financial dependence on the central budget that in this way 
question the term local selfgovernance. Such fiscal system characterized with grant transfers from central government in direction to those locals lead towards vertical and horizontal inequality. Numbers, based in our situation or based in other countries verify similarly that grants are not appropriate incomes for local governments. Under this basis we consider that the economic situation is miserable and that there is the last chance for the country economy to be in accordance horizontally and vertucally with the strategy for local economic development. This means that within this strategy the state budget should be tuned through fiscal policies and disbursement ones, giving more power and competence to the municipal institutions. Along with the progress during the last decade there were evidented some weaknesses that should be overcome in the up coming years. These weaknesses can be groupized in three main fields: first, Natioal Strategy of Drafting Policies; second, Legislation framework; and third, Competences and Capacities of Local Governance. The main weakness or the lack of a National Strategy for Drafting Policies is the failure of approving of a National Action Plan for decentralization and up to date there are not seen serious efforts in this direction. This is mainly because of the lack of the political will for creating of a mechanism at the national level for policies and that will co-ordinate and that will workd actively on drafting document of the national strategy for decentralization. The other weakness that contributes to this is the division of associations of the local governance that prevents the development of a coherent policy for local governance units. These factors have deterred efforts on promoting a political dialogue and building up a consensus that will produce a document of policies on decentralization at the national level.

Even though there was a considerable advancement in the general legislation cadre by entering into the force of various laws, the main weakness is the lack of acomprehensive law on local finances that will ensure a more logicall and sustaiable legal cadre. Existing laws have some big shortages and some inconsistencies that have been resources of conflicts at the country level. In some cases, as it is the tax for small businesses and domestic borrowing, normative atcts at the national level have affected, so the fiscal instruments could not use efficiently form the local governance units. At the local governance level, continuation of a number of small units from the local governance that are not able to offer services is a continual problem. Other weaknesses that create uncertainty with the structures of local governance are: the role of counties, joint functions that are not clearly defined, the lack of capacities on collecting of some resources and incomes especially tax on property and tax on small businesses as well as unpredictability of transfer for small units of local governance.

\section{Legal measures that should be taken for fiscal decentralization}

In accordance with the European Charter for Local Self-administration (European Council) ${ }^{2}$ that became integral part of Kosova legislation, the financial resources by which local governments are financed, then by all means they should be more competent based on the competences the local governments are responsible. A big part of resources, by which local governments are financed should derive from local taxes and compensations for what in accordance with the national legislation, local governments themselves determine the level and the financial resources by which the same will be enough and elastic to meet the needs of local governments. Starting from these obligations innovations should be evidented with the decentralization of local taxes, transfer of new competences in direction of local governments that will administer taxes and local compensations by which the responsibility will be influenced and increased in the process of administering wit the local own incomes.

In order to have a fiscal decentralization it is very neccessary a real plan to be realized on the depth of fiscal decentralization. This can be realized in two forms. The first, by concluding an agreement between the Ministry of Finances and the local governments and second, through changes, or promulgation of new legislation that will guarantee to the municipalities a bigger set of competences on the field of fiscla policies. Governmental Fiscal Policies in this aspect should be flexible, so in that way, they, to a high extent will acomodate to the needs of local development. Taking into the consideration that the municipalities from the Dukagjini region within their development strategies have tourism and hospitality, this should be done also with the possibilities od creating a legal basis in the aspect of collecting the budget incomes. In the aspect it is considered that the following measure should be undertaken:

\footnotetext{
${ }^{2}$ Republika e Kosovës respektivisht Asociacioni i Komunave të Kosovës e ka statusin e vëzhguesit në Kongresin e Autoriteteve Lokale dhe Rajonale në Evropë të Këshillit të Evropës. Karta Evropiane për vetëqeverisje lokale u aprovua nga Komiteti i ministrave i Këshillit të Evropës më 15 tetor 1985. Prej atëherë, Karta është bërë një akt fundamental ku është e përqendruar përvoja më e pasur e shteteve demokratike në fushën e organizimit të vetëqeverisjes. Karta është një trakt ndërkombëtar që e kanë ratifikuar 47 shtete nënshkruese të Këshillit të Evropës.
} 
1. The changes and amending the Law on VAT (Ligji RKS Nr. 03/L-114, 2003) by making partial increase. According to this concept the partial increase means that to the current VAT of $16 \%$ value we should add also VAT 2 of 2 or $3 \%$ value and this not in the entire state territory and only in the region where we have zones and places of touristic character and evnvironment valorization. VAT 2 should be applied only on goods and luxuries services so in that way that the social life and macro-economic stability of the country is not put in risk. This planned sum as VAT 2 will be easy to be collected because of the fact that there exist mechanisms and instruments for tax collection within the contry Tax Administration without additional costs. According to this proposal collected means from VAT 2 are guarenteed to be transfered to municipal budgets and this consequently brings investments in the zones where it is collected.

2. Changes and amending the Law nr. 04/L - 117 on ecologic and road taxes,( Ligji Nr. 04/L-117, 2012) concretelly changes of article 6 paragraph 2 so it oblige the Ministry of Finances to delegate competences on collecting ecological and road taxes taxes, to the local governments.

3. Changes and amending of Law $\mathrm{nr}$ / / 03/L-027 on taxes for accomodation in the touristic and hospitality objects , ( Ligjin RKS Nr. / 03/L-027, 2010) so the Ministry of Trade will transfer or allocate this tax in the municipal budget that indeed has collected it.

4. Promulgation of the Law on Local Administration where among the others it will be clearly regulated the possibilities and the determination of municipal abilities to borrow---they could do the same, they could create more suitable bank conditions realized by central financial institutions and at the same time the trust of banks towards the units of local self-administration will increase.

There are some additonal measures that accompany the legislative changes, and they are as follows:

a) Establishment of better mechanisms of reporting - local authorities report before citizens about the entire financial management of the municipality;

b) Possibilities for applying of additional resources for financing units of local administration as parts of tax on profits;

c) Long term we should increase the level of taxes on wealth by changing and completing the tax legislation. In the first phase local governments in the Republic of Kosova are encouraged to increase the level of taxes, taxes and local compensations in an maximal permited level;

d) Co-operation between municipalities should be stimulated in the sphere of tax administration, tax and local compensation sphere.

\section{Conclusions}

Kosova should be oriented towards creating of an open economy related to European market by implementing careful legislative policies in the spirit of economic liberalization. Our economic system should be characterized with the flexibility and it should be appropriate for integrations and it should stimulate domestic products in the region and more broader. Development of local economy is mainly conditioned by the government grants whereas the creation of a local fiscal system up until now remains only in a form of desire. This situation, that seems to be continuing had a negative impact and it didn't increase awareness for a better local fiscal culture amonf taxpayers that would impact directly economic development of commune and the better living standard. It is normal that fiscal policies in the Republic of Kosova should be proportional to principles of the open economy. This criteria makes it possible the incorporation with the current contemporary objectives of the micro and macro economic development of the country. But under the circumstances the country is passing through these policies should be be mix between local and central agencies. These should impact the stability of taxpayers and of Kosova Budget and its municipalities. In addition by stimulating foreign investments, economic development, economic growth and increase the employment as the new fiscal resources and that at the same time creates possibilities for long term economic and budgetart sustaiability. Decentralization can be sucessful only if accompanied by the fiscal decentralization. Local governments cannot exercise their funstions if they are not legally entitled to another needed resources. As a rule, local governments in our country have limited funds. Their basis of local resources is quite tight, not suitable or not achievable and thus local governments are very dependent on the intergovernment trasfers.

Fiscal transfers could be one of inter-government fiscal co-operation forms only and all the time there is a perception within the central instances there there is a doubt on the abilities of local governments to manage grants by efficiency and effectively. These transfers not only are needed but every delay in this segment will have a negative impact on the economic development. Even though planing and their implementation requires high administrative and economic 
cost, they are anyway needed especially in the countries in transition or those in development. Above all central government should this process of delegation of the fiscal competences and transfers to treat by priority. Communes that within strategies are positioned and convinced that touristic development, hospitality and environment are of primary importance, as it is the case with the municipalities of Dukagjini region, based always in concrete projects that are clearly studied, shoud be entitled this form of decentralization. This is possible to be realized based on the cretion of legislation by making urgently changes and amending the Law on VAT that means also the incorporation of a disposal allowing VAT 2 with an added value of 2 or $3 \%$ in touristic zones for goods and luxury services. These means should then go to the municipal budget. The same should be done by changing and amending the Law on Road and environment taxes i sense that the collected means should go to the municipal budget. In the every similar way we should act with the Law on taxes of accomodation on touristic and hospitality objects so the taxes belong to the municipal budget. Ministry of Finances should urgently sponsor the Law on Local Self-administration where among the others the possibilities for municipalities will be regulated and the abilities of municipalities will be determined so they could borrow, and on the other side other bank facilities will be created so the bank trust on th eunits of local administration will increase. Of course this is not an easy process but this is very necessessary and it should be accompanied with a series of legal acts and monitoring means as well as government control. Low economic development in the municipalities, not proper government grants and the lack of self budgetary means do not guarantee progress and based on this the poverty consequently continues. The change of the proposed legislative basis and the increase of the municipal budget will be a secure guarantee for gradual development of tourism and the local economy entirely.

\section{References}

Alison Jones, Brenda Sufrin EC Competition Law; Oxford University Press, 2007

Benatar SR. Linking Moral Progress to Medical Progress: New opportunities for the Declaration of Helsinki.

Pierre Salmon, Decentralization and Supranationality - The Case of the European Union: Université de Bourgogne November 2000;

Crook, R. dhe J. Manor (1998), Democracy and Decentralisation in South Asia and West Africa: Participation, Accountability and Performance, Cambridge: Cambridge University Press

Carlson RV, Boyd KM, Webb DJ. The revision of the Declaration of Helsinki: past, present and future. Br J Clin Pharmacol 2004; 57: $695-713$

Economic Decentralization and Local Government, The United States Agency for International Development Local Government Reform Project Croatia, Zagreb

The International Response to Helsinki VI - The WMA's Declaration of Helsinki on Ethical Principles for Medical Research Involving Human Subjects, as adopted by the 52nd WMA General Assembly, Edinburgh, October 2000

Fiscal Decentralization and Grants Transfer in the countries of transition: A critical perspective - NISPA cee Network of Institutes and Schools for Public Administration in The Central and Eastern Europe .

Williams JR. The Promise and Limits of International Bioethics: Lessons from the Recent Revision of the Declaration of Helsinki.

Carlson RV, van Ginneken NH, Pettigrew LM, Davies A, Boyd KM, Webb DJ. The three official language versions of the Declaration of Helsinki: what's lost in translation? J Med Ethics 2007; 33: 545-548

Schmidt U, Frewer A, eds. History and Theory of Human Experimentation: The Declaration of Helsinki and Modern Medical Ethics, Stuttgart: Franz Steiner, 2007

Public Coffers - towards efficient and transparent management of mnicipal budgets/KIPRED edition, Prishtina Mars 2011

Law on Finances of Local Government nr. 03/L-049. March 2008.

Law on Managing the public finances and responsibilities, nr. 03/L-048. Qershor 2008.

Law on Local self government, nr. 03/L-040. Shkurt 2008.

Kosovo Local Government Institute "Implementation of the Decentralization Process in Kosova - one year after the Constitution: Besnik Tahiri, Executive Director Instituti Kosovar për Qeverisje Lokale, (approached on 15.01.2014) www.fesprishtina.org/.../KLGI\%20Implementing 